\title{
Virtually There
}

\author{
Spectral Ireland and European Stereotypes in the Novels of Paul Murray
}

\author{
Aidan O'Malley
}

\begin{abstract}
Paul Murray's three novels, An Evening of Long Goodbyes (2003), Skippy Dies (2010) and The Mark and the Void (2015), constitute a humorous panorama of contemporary Ireland as they chart the ascent and supposed death of the so-called Celtic Tiger. This is an Ireland that has unmoored itself from history and has replaced the dilapidated spiritual authority of the Catholic Church with the guidance offered by the invisible hand of the free market. When this Irish iteration of late neoliberal capitalism failed, the country found itself incapable of imagining any real alternative to it. This contribution illustrates how these novels employ non-Irish European characters to dramatize this process. During the boom years Ireland came to encounter Europe much more directly than before through inward migration, especially from parts of the continent that had not featured in earlier cultural and political constructions of Europe. Murray's novels explore how the stereotyping of European immigrants was essential to the operations of the phantasmagoric Celtic-Tiger Ireland. However, as this essay also shows, the comic exaggerations employed in the satirical representation of this spectral dynamic in Murray's most recent novel gesture back towards, and repeat, the stereotyping the novel is explicitly critiquing.
\end{abstract}

Set in the years of the so-called Celtic Tiger and the subsequent economic crash, Paul Murray's three novels, An Evening of Long Goodbyes (2003), Skippy Dies (2010), and The Mark and the Void (2015) are, in many respects, ghost stories. Charles, the protagonist of An Evening of Long Goodbyes who compares himself to Hamlet, struggles to come to terms with his father's death and tainted legacy; the students in Skippy Dies deal with the trauma of Skippy's unexpected death by constructing a time machine to communicate with him; The Mark and the Void conjures up French thinkers such as Jean Baudrillard and Guy Debord to frame the materialization of zombie banks in the country. Recognisable and comically unreal, the spectral Ireland of these novels is a place in which other-worldly forms of reality are ending. In An Evening of Long Goodbyes Charles is cast out from a salubrious Dublin Garden of Eden, while

(C) AIDAN O'MALLEY, 2021 | DOI:10.1163/9789004436107_015

This is an open access chapter distributed under the terms of the CC BY-NC-ND 4.0 license. 
Skippy Dies charts, amongst other things, the declining spiritual authority of the Catholic Church; unable to compete with the hold that the free market has on the country, these superannuated modes of living are being supplanted by it - a process the novels present as a case of one form of virtual reality replacing another. The illusory nature of this hegemonic economic ideology is the theme of The Mark and the Void, which is set in the immediate aftermath of the 2008 global banking crisis and the collapse of the myth that property prices could only increase. However, as the novel registers, despite this painful unveiling of the chimerical nature of capitalism, it is superseded by an even more unreal version of itself. In short, the Ireland of these novels marks an emptiness that struggles to register a semblance of presence that might transcend the constricted dogma of the unregulated free market.

Skippy Dies (2010)

As is well known, after decades of being the poorest country in Western Europe, the Irish economy took a turn towards unthought-of prosperity in the 1990s thanks to a combination of EU funding, a low corporate tax regime, and a well-educated, Anglophone and cheap labour force. Attracted by this, large international corporations, especially from hi-tech sectors such as information technology and pharmaceuticals, pitched up in Ireland. Set in this moment, Murray's most successful novel, Skippy Dies, portrays a country that, as a consequence of this massive economic adrenaline hit, has achieved Stephen Dedalus's ambition of awakening from the "nightmare" of history, and is now wallowing in the daydream of consumerism. ${ }^{1}$ Skippy Dies views the Celtic Tiger years from the perspective granted by an expensive Dublin Catholic boarding school, Seabrook (modelled on Blackrock College, Murray's alma mater), where the students absorb much of the world through the stereotypes that drive fantasy and combat computer games, television shows and films. Under these influences, they relate to the past in a lexicon drawn from the likes of Dungeons and Dragons - invariably referring to history as "days of Yore" - while US films about Vietnam provide the epithets with which they racially abuse the young Chinese man and woman working at their hangout, calling them "Gook", "Gookette" and "Charlie". ${ }^{2}$ But what the novel underlines is that the teenagers' attitudes to the past are confused precisely because most of

1 Joyce (1986), p. 28.

2 Murray (2010), pp. 40-43. 
the adults around them have even less appreciation of history. Many of the younger teachers are, or aspire to be, "kidults", as one of that cohort notes living out of time and as concerned as their students are with the latest shiny gadgets. ${ }^{3}$ The students' parents' emotional lives evince no signs of maturity; all that distinguishes them from the younger generations is the more elevated bracket of consumerism they operate in.

Dealing, as it does, in 'futures' not 'pasts', capitalism is inherently ahistorical, and "[t]he Irish", according to Halley, an American living in the Dublin of this novel, "are all about the future". 4 George O'Brien has suggested that the characters in this novel "stumble through a mismanaged and fragmented present without the remotest idea of what difference their doing so will make to securing a future." While it is the case that the school, like the society in which it is embedded, is fundamentally lost, it is perhaps more accurate to say that the novel portrays a community that can only imagine finding itself through immersion in the shrunken future promised by the free market.

"There's a little banker inside all of us now", was Murray's diagnosis of the national psyche in a 2015 interview, and Costigan, Seabrook's interim principal, sees it as his job to nurture and spread this virus. ${ }^{6}$ In spite of his excesses, he is less a comic grotesque than an embodiment of the worst aspects of boom-time Ireland: his glib conflation of 'reality' with 'consumerism' regurgitates the shibboleths of politicians and journalists that passed as indisputable wisdom for most of the two decades leading up to the $2008 \mathrm{crash}$. In common with them, Costigan sees himself as a moderniser, especially as he will be the first non-religious principal of the school, which was founded, and has been always been run, by an invented order of priests called the Paracletes. The spirituality of this community is evident in its name: 'paraclete' in Christian theology refers to "the Holy Spirit as advocate or counsellor". ${ }^{7}$ Priests adhering to such a vision of their roles are "outmoded technology" to Costigan's mind: too tied up in the past, and too non-materialistic to prepare the boys for careers in business, which has become the school's raison d'être. ${ }^{8}$ For Costigan, education should be entirely focused on "[r]eality" and "objective, empirical truths." ${ }^{9}$ These

\footnotetext{
3 Murray (2010), p. 62.

4 Murray (2010), p. 82.

5 O'Brien (2012), pp. 183 f.

6 Coffey (2015).

7 Oxford English Dictionary. http://www.oed.com/view/Entry/137308?redirectedFrom=paray clete\# eid [accessed 28.10.2017].

8 Murray (2010), p. 94.

9 Murray (2010), p. 93.
} 
are just a couple of the empty platitudes that mould his self-serving debased utopian vision, about which he, notably, daydreams:

although the Paracletes may be gone, for all intents and purposes, their values live on. Maybe the men upholding them will wear a suit and tie instead of a dog collar; maybe they will carry a laptop instead of a Bible, and maybe 'common business model', not 'God', will be the name of the bridge they use to bring communities together. But although appearances may change, the values themselves remain the same - the Seabrook values of faith, decency, various others. ${ }^{10}$

Looking to frame this break with the past in terms of a continuity, this is advertising jargon posing as a credo. History, religion and tradition are not to be jettisoned entirely; rather, they are valued exclusively as unique selling points. They are the intangibles that establish "a strong brand identity", and, as Costigan puts it, "[b]rands rule the world today. People like them. They trust them."11

Importantly, Murray's presentation of this battle for the school's soul is nuanced, and never offers a black-and-white portrait. While the clichéd banality of Costigan's mendacious and ultimately successful project is the main object of this satire, the priests are hardly advanced as a superior alternative. Father Green, a French teacher who has served on the African missions, is the most implacably hostile opponent of Costigan's mercenary programme. The students, though, call him "Père Vert", and his never-fully-articulated dark past points to the brutality and paedophilia that have irredeemably stained the history of the Catholic Church's control of education in Ireland. ${ }^{22}$

The constraints imposed on Ireland by the Catholic Church have now been replaced with those of debt. The pervasiveness of capitalism - how it binds one's affective life to economics - can be witnessed in how Halley tells her partner, Howard, that it is "simple economics" to get a mortgage and set foot on the so-called property ladder. ${ }^{13}$ But, as she is semi-consciously aware, she also views Howard's assumption of this long-term, massive, debt as a sign of commitment to their relationship. Putting a monetary value on their future is an attempt to make it less indefinable, but, as they soon discover, this is a delusion. Michael Hardt and Antonio Negri have traced how the liberty promised by the free market is always a mirage, because it is based on creating a

\footnotetext{
10 Murray (2010), pp. 6o7f.

11 Murray (2010), p. 91.

12 Murray (2010), p. 70.

13 Murray (2010), p. 8o.
} 
population of the "indebted" whose lives have "been put to work". As such, it is an insidious, ubiquitous, system of control:

[b]eing in debt is becoming today the general condition of social life. [...] Your subjectivity is configured on the foundation of debt. You survive by making debts, and you live under the weight of your responsibility for them. Debt controls you. [...] Debt wields a moral power whose primary weapons are responsibility and guilt, which can quickly become objects of obsession. You are responsible for your debts and guilty for the difficulties they create in your life. ${ }^{14}$

Throughout the first decade of the twenty-first century, Irish politicians, commentators and journalists enjoined the country to get itself into as much debt as possible. Fuelled by an unholy alliance of unregulated banks, politicians and developers, Irish property prices sky-rocketed in the years leading up to the 2008 crash. These banks, as L.M. Cullen observed, "broke[] every rule in the canon of banking" with the result that Ireland was, along with Iceland, "the most extreme case of the widespread folly in the world banking system."15 The idea that property values might stop rising - that history had shown that this bubble was unsustainable - had to be clamped down upon and ridiculed, for fear it might puncture the illusion that sustains capitalism: that it can unshackle itself from the past and create an entirely new future simply by repeating the same operations. Notoriously, in 2007 the then Irish Taoiseach, Bertie Ahern, dismissed the economist Morgan Kelly's warnings that the overheated property market would collapse by wondering how he and other commentators who were "sitting on the sidelines, cribbing and moaning", "don't commit suicide". ${ }^{16}$ When the accuracy of Kelly's prognostications became evident just a year later and Ireland underwent the worst economic crash experienced by a developed economy since the Great Depression, the moral power of debt that Hardt and Negri describe was recruited to deflect criticism of the ruinous ideological decisions made by successive Irish governments: when the debts were suddenly called in, neoliberal politicians and

\footnotetext{
14 Hardt, Negri (2012).

15 Cullen (2012), pp. 14f.

16 RTÉ (2007). As can be seen in this news report, Ahern subsequently apologised for taking suicide too lightly, but not for his repudiation of those experts who refused to join in the chorus boosting the economy.
} 
commentators worked to foster the view that blame for the meltdown must also be apportioned to the Irish people for having "partied" too hard. ${ }^{17}$

Before the 2008 crash, the future that these free-market ideologues imagined was most fully embodied in the United States; as Halley notes in Skippy Dies, "an American accent was [...] the Voice of Authority, and anything it said [is] treated as dispatches from the mother ship."18 This reflects the perspective that was most clearly articulated in July 2000 by the then Tànaiste (Deputy Prime Minister) Mary Harney, who claimed that "[g]eographically we are closer to Berlin than Boston. Spiritually we are probably a lot closer to Boston than Berlin." ${ }^{\prime 19}$ On one level, this is merely an Irish brand of the sort of right-wing populism that helped fuel Brexit: favouring the dream of American unregulated neoliberalism over the stereotype of European welfarism (which, in Ireland's case, left it hugely exposed to the US sub-prime mortgage meltdown). ${ }^{20}$ However, phrasing this bias in terms of a spiritual inclination signalled, perhaps unwittingly, a sense of cultural rupture not just with the authority of the Roman Catholic Church, but also with an idea of Europe that played a key role in the development of the bourgeois Ireland Harney would have claimed to represent.

\section{$2 \quad$ An Evening of Long Goodbyes (2003)}

As is most fully articulated in the pages of The Bell journal (1940-54) and in the work of one of its editors, Seán O'Faoláin, many twentieth-century Irish writers and thinkers were disposed to construe an idealised Europe that always already stood in opposition to everything Irish: a place beyond the pulls of nationalism, where rational debate and artistic freedom flourished. Fundamentally existing as a symbol of the secular modernity that Ireland had yet to achieve, this spectral Europe embodied a style that dreary Ireland struggled to emulate, be it in terms of architecture, cuisine, fashion or, simply, a way of life. As such, this vision of Europe played a key aspirational role in the development of middle-class Irish liberalism. Entry into the European Economic Community in 1973, and the increased interactions with European countries

17 For instance, Brian Lenihan, the then Minister for Finance, argued that "we all partied" in a 2010 interview; Lenihan (2010).

18 Murray (2010), p. 82.

19 Harney (2000).

20 As the Nobel laureate economist, Paul Krugman, put it: "How did Ireland get into its current bind? By being just like us [the US, A.O'M.], only more so." Krugman (2009). 
that came with this, did little to disrupt this vision. ${ }^{21}$ Attitudes to Europe only began to change with the advent of Irish prosperity: it was then that proselytizers like Harney began to promote the idea that the country was more properly part of a neoliberal Anglosphere. This coincided with a considerable disruption of the stereotype of Europe: due to the numbers of Central and Eastern European citizens arriving in Ireland, it became increasingly difficult to see Europe exclusively as Western Europe.

European immigrants in Ireland feature prominently in An Evening of Long Goodbyes and The Mark and the Void. Murray's first novel, An Evening of Long Goodbyes, tells the tale of Charles, a wastrel scion of a wealthy Irish family who is drinking his way through the family's cellar. Since his father's death, his mother's hospitalisation for alcoholism and his failed romance with Patsy Olé, he has cocooned himself inside the family estate, away from what he sees as the tainted modern world. He is literally living in a utopia, a no-place that is also a place of happiness: the family house is called Amaurot, which is the capital of Thomas More's Utopia, and his surname, Hythloday, (literally the 'speaker of nonsense') nods to Utopia's Ralph Hythloday, the discoverer of Utopia who refuses to consider being an advisor to the monarch, as such proximity to government would endanger his ideals. ${ }^{22}$ Charles too remains aloof from any form of civic engagement and, initially, very little of Celtic-Tiger Ireland impinges on his consciousness, even if he has heard disturbing tales of the newly-rich circling vulture-like in the vicinity of his demesne: solicitors and bankers in expensive new cars offering fabulous sums for the sort of properties that would grant them a facade of aged respectability. However, his insulation from events beyond his walls is punctured when he discovers that he is a member of the ranks of the indebted: his father purchased Amaurot through an intricate series of dubious mortgages, the payments on which are now so overdue that the banks are threatening foreclosure. Charles devises a hare-brained plan to swindle the family's insurance by exploding a folly he was constructing in the gardens, and when this literally blows up in his face he is cast out from his gilded life.

While the fallen world beyond is harsh, it too seems to operate in a rather fabulous fashion. In particular, Charles discovers that the employment practices that underpin Ireland's booming economy have little contact with the real lives of the workers. Interviewed for a job by the director of a company called 'Sirius Recruitment', Charles is engulfed in the bromides that constitute

\footnotetext{
21 For an overview of the literary constructions of Europe in this period, see O'Malley (2020).

22 Noting that "the telephone company that threatens to buy out Amaurot from the dithering, Hamlet-esque Charles and his Ophelia-like sister is named Telsinor", Stephen Amidon felt that "Murray has a rookie's weakness for literary allusion". Amidon (2004).
} 
the new economy: he would, for instance, not be so much an employee as "a Sirius partner", because, as the director phrases it, "although I'm head of the company, I like to say that I'm working for you."23 These inanities ultimately translate into a job straightening yule logs as they chug along a production line in a bread factory. There was, though, some truth in the director's statements, as it transpires that Charles is not employed by Sirius, "but by its sister company, Pobolny Arbitwo Recruitment." ${ }^{24}$ In fact, he is one of the very few Irish workers on the factory floor: most of the rest are Latvians who are fundamentally indentured to Pobolny Arbitwo, which takes a large percentage of their meagre salaries for having furnished them with a job, and for items such as the barracks-style accommodation it provides. When, without any warning, the workers are told that they are to be laid off and replaced by robots, the everyday chicanery of the arrangement is laid bare: not only do many of the workers discover that, after all the deductions, their final salaries amount to precisely nothing, but they also learn that they are owed no redundancy payment, as they are still employed by the recruitment agency, which was leasing them to the factory. These are the ghosts operating the machinery of Celtic-Tiger Ireland: fabricated companies, nested inside each other like matryoshka dolls, that render the idea of work itself fictitious and grant their immigrant employees little more than a wraithlike existence.

These were not, though, the first immigrants from Central and Eastern Europe that Charles had encountered. In his Edenic persona, he regally described his housekeeper at Amaurot, "Mrs P", as "the help. Bosnian, you know. Or is it Serbian? An absolute treasure, anyway. [...] if there's one good thing to come out of all this fuss in the Balkans, it's the availability of quality staff". ${ }^{25} \mathrm{Mrs} \mathrm{P}$, it is later learnt, had not trained as a cook, but had been a lawyer in Yugoslavia, before the wars there ripped her family apart. She and her family, who are discovered living in the folly that he blew up, came from the Krajina, an area in Croatia bordering Bosnia that had a majority Serb population. And just as Hythloday points to Charles's nonsensical, utopian character, their difficult, 'unpronounceable' surname - "Pribicevic" as the novel gives it - signals the end of a dream: Svetozar Pribičević was a politician who campaigned in the first half of the twentieth century for a Serbian and Croatian federal state. Murray, in other words, has given this family a very specific, hybrid, home and identity. Yet, despite these explicit details, everyone in the novel remains hazy about where exactly they are from - having no real knowledge of Yugoslavia

\footnotetext{
23 Murray (2004) p. 223.

24 Murray (2004), p. 255.

25 Murray (2004), p. 6.
} 
and not feeling that it was worthwhile making the effort to know anything about the family's background, they remain exotic Balkan ghosts. Tellingly, this was also true of a number of contemporary reviews of the novel, which seem to have taken Charles (despite his clear fogginess) at his word, and granted the family a Bosnian origin. ${ }^{26}$ While that is inaccurate, it is, at least, geographically proximate; they are bizarrely "Kosovan" in Aisling Foster's Irish Times review. ${ }^{27}$

Although most of the Irish characters absorb this family's history as superficially as they might a piece of horror or fantasy fiction, it strikes one of the more realistic notes in this metafictional comic novel. Amongst other things, the mock-nostalgic take on the advent of the Celtic Tiger in An Evening of Long Goodbyes is a pastiche of Irish 'Big House' literature. The 'Big House' was where the, generally but not exclusively, Anglo-Irish, Protestant ascendancy lived and controlled the lives of the, generally, impoverished Catholic peasant tenants who worked on their estates. 'Big House' literature utilises this potent physical symbol of the historical divides in Irish life, and while this genre has taken different forms, some of the most noted examples of it, such as Yeats's 'Coole Park 1929' and Elizabeth Bowen's novels, have evinced a nostalgic and elegiac vision of a world of culture and civilised living fading away in the face of a rising nationalist, Catholic, philistine middle class. Notably, the Hythlodays' religion or cultural affiliation would appear to be unimportant in Celtic-Tiger Ireland. The novel plays with our assumptions that they are Anglo-Irish and Protestant - Charles dabbled for a year with Theology at Trinity College Dublin, and his manners and attitudes are those associated with the pre-World War II British aristocracy - but this is by no means necessarily the case; his sister, Christabel, for instance, had been educated by nuns. Rather, the Hythlodays are merely aping the 'Big House' affectation of a cultural aloofness from the capitalism that has created the family's wealth.

This mock-aristocratic attitude is given a supplementary Eastern European frame, as Chekhov's The Cherry Orchard is a constant intertextual presence in the novel. Reviewing Frank McGuinness's 1995 version of Uncle Vanya, Irving Wardle noted that "Chekhov over the past 20 years has become an honorary Irish author", ${ }^{28}$ and the novel riffs on the by-now considerable theatrical tradition established by dramatists such as McGuinness, Thomas Kilroy and, most notably, Brian Friel that links Chekhov's world of gentle decline with Irish historical experience. However, despite the fact that the theme of The

\footnotetext{
26 See, for instance, Fennelly (2003); Reyn (2004).

27 Foster (2003).

28 Wardle (1995). Reviewing the same production, John Keyes was driven to capitalise his frustration, declaring that "CHEKHOV IS NOT IRISH". Keyes (1995).
} 
Cherry Orchard - the failure to save an estate - speaks to the family's situation, and that the foregrounding of a classic of Russian literature might be thought to offer an oblique commentary on the ways in which immigrants from this region are stereotyped and treated in contemporary Ireland, Chekhov's drama's primary function in An Evening of Long Goodbyes is to place the world of the novel behind one more lens of fictionality. Everything and everyone in this novel is essentially mimicking or citing something else. If the protagonist's language, with its 'gimlets' and 'Pongos', has been learnt from P.G. Wodehouse, the plot of this novel is more indebted to Evelyn Waugh's laconic unveiling of an Eden's dark underbelly. Importantly, the Irishness of this world is also largely the product of literature: W.B. Yeats's Celtic wistfulness and Oscar Wilde's aristocratic socialism are touchstones in the protagonist's upbringing, and MacGillycuddy, the all-knowing, if not entirely reliable, postman who organises fake deaths and new lives, has stepped from the pages of a Flann O'Brien novel (The Third Postman perhaps?). In short, the novel constantly vaunts its virtuality, the fact that it is all made up: although Charles likes to pretend that the family's wealth is an aristocratic inheritance, it actually derives from his father's skill in concocting cosmetics - the whole edifice is literally built on makeup.

\section{The Mark and the Void (2015)}

"Idea for a novel" are the first words of The Mark and the Void, which is yet more emphatically a metafictional novel, even if it is peculiarly uncomfortable in that skin. ${ }^{29}$ It surveys the causes of Ireland's economic collapse and, to a lesser degree, the wreckage it wrought, from the perspective of Claude Martingale, a Frenchman working in what he terms "shadow-banking" in the "shadow-place" that is Dublin's International Financial Services Centre (IFSC). ${ }^{30}$ Citing François Texier, the fictional French philosopher whose non-presence lies at the heart of this novel, Claude describes the IFSC as an archetypal virtual location: it is "real without being actual, present without being there". ${ }^{31}$ For Paul, a writer whose surname we never learn, the international anonymity of the IFSC - the fact that it could be anywhere and so "[b]eing here means not being here" - renders it the quintessential location of "modern life". 32 Inhabiting this liminal non-place makes Claude a prototypical twenty-first-century

\footnotetext{
29 Murray (2016), p. 1.

$30 \quad$ Murray (2016), p. 23.

31 Murray (2016), p. 23.

32 Murray (2016), p. 15.
} 
Leopold Bloom, a contemporary Dublin Everyman. For this reason, Paul wants to model his next novel on Claude, and proposes shadowing him for a period to deepen his understanding of his life and work. But, as the reader knows from the second half of the novel's first sentence - "we have a banker rob his own bank" - these literary intentions are simply window-dressing for a scam to infiltrate and steal from Claude's bank. ${ }^{33}$ Paul's preposterous plan comes to nought because, as Claude points out to him, the bank has no actual, tangible, money on its premises; just as Paul's heist is based on nothing more than a never-to-be novel, the substance of this bank is virtual, merely numbers flashing on computer screens.

The intersection of business and aesthetics is a theme that runs through these three novels. Skippy Dies traces how, by stripping away values that might sustain art, a business culture delivers a world in which the quality of a piece of classical music is evaluated from its use in a Citroën car advertisement. An Evening of Long Goodbyes takes a sardonic look at a would-be alternative and socially-concerned theatre troupe and its ready embrace of sponsorship from a large telecommunications corporation that thinks having a little 'edge' might be beneficial to its image - a union that is greatly facilitated by their shared fluency in vacuous non-speech. In The Mark and the Void Claude's colleagues are surprisingly excited to have a novelist take an interest in their lives: faced with the virtuality and dullness of their work, they look to fiction to offer narratives that might make sense of their condition. Indeed, these bankers are some of the few characters in the novel who have any conviction about the usefulness of art and literature.

More generally, a deep disillusionment with literature can be detected in The Mark and the Void, a novel full of writers losing faith with writing. After his first book failed to launch him into literary stardom and its attendant financial advantages, Paul's days are now spent either in lap-dancing clubs or concocting bizarre schemes for making a quick buck. In contrast, the literary sensation du jour, Bimal Banerjee, declares his intention to retreat from the world of letters in order to place himself beyond the reach of the marketplace. Disenchanted with philosophy, Texier turned to painting, and even though he refused to sell his paintings, they nonetheless made their way into the market, causing him to give up that art form as well. One of his most famous pieces, Le Marque et le Vide, 'The Mark and the Void', ends up on the wall of a successful Irish writer and his banker partner in Dublin. It is described as: "[w]ords upon words upon yet more words; hundreds of 
pages of text superimposed one on top of the other, rendering each other utterly illegible - creating instead a cascading darkness that seems to devour the very possibility of meaning." ${ }^{34}$ In a not entirely dissimilar fashion, the palimpsestic, metafictional form of The Mark and the Void stresses its spectral nature: this is a novel that, in a deliberately perverse way, appears to be struggling to unwrite itself as it unfolds.

This disquiet about the meaning of literature largely stems from the novel's insecurities about the necessity and possibility of fiction writers articulating the operations of international finance. As this sector is fundamental to so much of contemporary life, the novel constantly argues for a fictional engagement with it. Yet, in the same moment, it raises doubts about the ability of fiction to communicate the hegemonic, incoherent, meaninglessness of the make-believe world of the free market; a universe where, for instance, the apparently huge wealth that was generated in the years of the Celtic Tiger could seemingly disappear overnight: "[ $t$ ]he banking crisis", in Banerjee's succinct terms, "is unrepresentable". ${ }^{35}$ Nonetheless, a considerable amount of The Mark and the Void is devoted to unveiling and explaining the magical thinking that characterises contemporary finance. In fact, as the novel's fictional philosopher, Texier, points out, businesses have an essentially mythical basis:

what we call the corporation [...] first appeared in Europe's Middle Ages, signed into law by the Pope in AD 1250. It was conceived as a legal persona ficta - a 'fictive person' that had many of the attributes of a real person. It was capable of owning property, for example, of suing and being sued; at the same time, it was bodiless, invisible, free from human infirmity and the ravages of time. Conceived as such, the corporation was almost identical to contemporary ideas of angels. [...] the corporation, an entity which we imagine as a uniquely secular creation, a paragon of reason and common sense, in fact began its life as an offshoot of a Christian myth. ${ }^{36}$

The priesthood who keep this flame alive is composed, for the most part, of young male bankers who are so immersed in the angelic, virtual, ever-present they cannot determine their desires for corporeal women until they have photographed them on their phones. History is only relevant to the extent that it presents them with a challenge to make more money for themselves and their fabulously wealthy clients in the future.

\footnotetext{
$34 \quad$ Murray (2016), p. 328.

35 Murray (2016), p. 331.

$36 \quad$ Murray (2016), p. 265.
} 
This arrogant ahistoricism is dictating the direction of Claude's employers, the Bank of Torabundo, an investment bank that has survived the financial crisis thanks to the conservative approach of its CEO, Sir Colin, who avoided "toxic investments" as he "was deeply suspicious of complex derivatives". ${ }^{37}$ Surrounded by the wreckage of failed competitors, this prudence has transformed Torabundo into an important player, and it seeks to build on this standing by sacking Sir Colin and replacing him with Porter Blankly. He is spoken of as a financial demigod both by the bankers and by the financial press despite having been the guiding light at Danforth Blaue, "one of the biggest casualties of the crash" that "needed a fifty-billion rescue package from the US government". ${ }^{38}$ Living up to his name, the always off-stage Blankly issues occasional gnomic emails to his employees, who regard them as Delphic riddles they must decipher. In brief, he occupies the higher echelons of the seemingly untouchable pantheon of contemporary alchemists who seek to turn corporate and national losses into profits for themselves and their wealth-fund clients. ${ }^{39}$ Claude, who does not entirely buy into this esoteric thinking, discovers how it operates when he is given the prestigious task of preparing a report for the Irish government on the largest failing bank in the country, the Royal Irish Bank. As he quickly realises, this is a completely unsustainable entity that never had any substance at the heart of its labyrinthine, fictional, accounts. However, his report advising that the bank get no more public money and be shut down is not what the government or his bank wanted to hear: their priority is to protect the bank's wealthy international bondholders, which entails keeping the money flowing. Claude's report is redacted, and the government presents it as an endorsement of its policy of pretending this persona ficta were alive. Thus, rather than as a result of inscrutable theorems devised by the enigmatic Russian mathematicians the bank employs, this contemporary financial alchemical process is revealed to work in a much more mundane fashion: through massive misappropriations of public money this so-called zombie bank continues to generate profits for the super-rich.

Scandalously, this happened in Ireland on 29 September 2008, when the government decided to provide a 100\% guarantee for the "deposits and debts"

\footnotetext{
$37 \quad$ Murray (2016), p. 40.

$38 \quad$ Murray (2016), p. 41.

39 According to Murray, these characters are more congenial than real bankers: his research revealed " $[\mathrm{t}]$ he preposterous machinations of these people who we still think of as being sane and sober individuals. But they're not. They're basket cases [mad, A.O'M.]. The banks were full of basket cases, people who had lost any connection to their responsibilities as human beings." Wallace (2015).
} 
of Ireland's embattled banks, the most insolvent of which was Anglo-Irish Bank, which had been named the world's best bank in 2006 by the still highly-reputed international consultancy firm, Oliver Wyman. ${ }^{40}$ Agreed to by the then Minister for Finance, Brian Lenihan, this guarantee, as Fintan O'Toole put it, maintained "the fiction that [Anglo-Irish] was a viable bank" by making Irish tax-payers responsible for all its debts. ${ }^{41}$ Like other noisy champions of deregulated banking, Seán FitzPatrick, who had helmed Anglo-Irish into these rocks, turned to public money when the invisible hand of the market proved to be precisely non-existent. Identifiable versions of these events and characters are to be found in The Mark and the Void, and if it might seem "unfair, even imprudent to write of a dying, and potentially recognisable, minister for finance", ${ }^{42}$ as Eileen Battersby put it in her notoriously scathing review of this novel, it is also the case, more generally, that the representations of the personae fictae in this book are marked, in different ways, by a problematic shifting equilibrium between the realistic and the spectral.

If the masks fabricated here for some of the principle actors in Ireland's actual crash are deliberately transparent, the fictionality of many of the other characters in this novel is accentuated. As in The Evening of Long Goodbyes, one way this artificiality is emphasised is through their names. Claude's surname, Martingale, wryly points both to his understated character, as it signifies "a strap or set of straps [...] used to prevent the horse from raising its head too high", and to the fiction underlying his profession: it also names "a gambling system of continually doubling the stakes in the hope of an eventual win that must yield a net profit."43

Other characters in this novel, though, manifest a more troubling form of virtual reality. The epigraph for section three of The Mark and the Void is the opening sentence of Guy Debord's 1967 Society of the Spectacle, which, in many respects, sets the scene for the world of this novel: "[i]n societies where modern conditions of production prevail, all of life presents itself as an immense accumulation of spectacles. Everything that was directly lived has moved away into a representation." 44 Stereotyping, which offers a debased, fictionalised, rendition of lived reality, provides a vocabulary for many of the characters in

\footnotetext{
40 Murray-Brown, Dennis (2008). While this report has vanished from Oliver Wyman's site, a copy can be found at Cotterill (2011).

41 O'Toole (2010), p. 208.

42 Battersby (2015).

43 Oxford English Dictionary. http://www.oed.com/view/Entry/114453?rskey=4Z4brH\&reE sult=1\#eid [accessed 28.10.2017].

Murray (2016), p. 263.
} 
this novel and, thanks to the toxic masculinity that drives both places, communication in the offices of Torabundo frequently echoes that which might be heard in the schoolyards of Skippy Dies. Claude is known as the "Crazy Frog" to his colleagues, ${ }^{45}$ and the fiction of national stereotyping appears to be a way in which these deracinated bankers try to ground each other and negotiate their bewildering virtual world. More importantly, the novel further suggests that this recourse to crude stereotypes plays a guiding role in the policies of these institutions. As he dispassionately explains the massive Ponzi swindle that his bank has perpetuated by getting the Irish public to shoulder its debts, Jurgen has no doubt that the Irish will take this calmly, as they "are at root a slave race" that "until very recently [had been] ruled by priests" and, as a result, "believe they are born in debt". ${ }^{46}$ Just as the profits generated by the Celtic Tiger were indisputably international while the losses became entirely Irish, this German character illustrates how global capitalism is only superficially post-national.

Nowhere, though, is this more apparent than in the treatment of the Eastern European characters in The Mark and the Void. If, as Jurgen indicates, Ireland is now viewed as a subordinate European nation (one that is far from indulging in fantastical debates about which side of the Atlantic it belongs to), the novel constantly marginalises characters from the post-communist flank of the continent. At the periphery of the narrative we find mad Russian geniuses who live in cupboards, Bulgarian drug dealers, and "gaunt Slavs with chilly eyes". ${ }^{47}$ Igor and Clizia, the two most important Eastern European characters, are nothing more than stereotypes. Igor is a servile, grotesque heavy, who cannot even bear to look at the art on display in a café. And while Clizia is imbued with considerably more dignity, she is ultimately a cipher: named after the nymph who transformed herself into a sunflower after the sun had rejected her, she is never anything more than a lap dancer and Paul's long-suffering, loyal, wife. Crucially, she is from nowhere; or, rather, from an entirely invented state. Clizia, as Paul explains, is from "Ectovia. Used to be part of Makhtovia, then when Transvolga seceded from Makhtovia it became a subdistrict of Transvolga. Then it seceded from Transvolga, to become the Ectovian Free Democratic Republic." ${ }^{48}$ While Transvolga exists as a region, neither Ectovia (which

\footnotetext{
45 Murray (2010), p. $26 f$.

46 Murray (2016), p. 443.

47 Murray (2016), p. 246.

48 Murray (2016), p. 167. Although he is by far the more irredeemably stereotyped character, Igor is given an actual homeland. Reminiscing about his wife, yet again a stripper, who "must be fifteen now", Igor reveals that he comes from the "Transnistrian Autonomous
} 
perhaps plays on the German echt 'authentic') nor Makhtovia (the German for power is Macht) can be located. ${ }^{49}$

Vesna Goldsworthy has documented how British popular fiction writers in the nineteenth and twentieth centuries regularly invented Balkan countries such as Ruritania to grant their tales an exotic, decidedly other and politically volatile, locale: "[a]mid the general embourgeoisement which [...] made most of Europe appear too dull for romance, only the Balkans seemed to escape the 'intrusion of civilised monotony', as H.H. Munro (Saki) [put it]". ${ }^{50}$ Through a reading of Malcolm Bradbury's Rates of Exchange (1983), Kazuo Ishiguro's The Unconsoled (1995) and Jim Crace's Six (2003), Hywel Dix's updated supplement to Goldsworthy's study found that while "the end of the Cold War, the expansion of a global economy and the prospect of an expanded European Union might have been expected to be accompanied by a shift in discursive representations of the cultures and societies of Eastern Europe", this has not happened. ${ }^{51}$ Instead of "addressing the specificities of actually existing Eastern European societies", these novels present "a series of Eastern European societies that are emptied of content".52 In conspicuous contrast to the rendering of the Pribičević family in The Evening of Long Goodbyes, Clizia's fictional background serves as nothing more than a stereotype of the worst excesses of the supposedly unimaginable (to a Western European) ethnic fragmentation of the post-communist world. It casually describes a history that has brought about a set of literally meaningless states, presumably concocted from the stereotypical Eastern European propensity to reanimate ancient nationalisms, religious divides or other forms of authoritarianism. In other words, Clizia's virtual homeland represents the belated forms of experience that Ireland - which has regularly been thought to have shared a history of 'ethnic nationalism' with Eastern Europe - has left in its wake in its journey towards the impalpability of the free market. ${ }^{53}$ No doubt The Mark and the Void wants

Region" in the "former Soviet Union" - a disputed area in Moldova between Ukraine and the Dniester river. (p. 26o).

49 Echoes might perhaps also be heard of Makhnovia, a stateless 'Free Territory' that sought to function as an anarchist society from 1918-21 in present-day Ukraine.

$50 \quad$ Goldsworthy (1998), p. 43.

$5^{1} \quad$ Dix (2015), p. 989 .

$5^{2} \quad$ Dix (2015), p. 989.

53 Hans Kohn, for instance, offered an influential, geographically-defined distinction between civic and ethnic nationalisms: if Western European nationalism was cast as civic, its Eastern counterpart was ethnic. This neat metaphorical arrangement was somewhat disrupted by the fact that Ireland was assigned to the ethnic camp. See Kohn (1945), pp. 329-34. 
to portray Clizia and the other Eastern European immigrants as the ultimate victims or embodiments of what Debord called the "[s]pectacular power" of global capitalism. ${ }^{54}$ However, their extremely stereotypical configurations not only frustrate this ambition, but also ineluctably throw into counterintuitively positive relief the chimeras of embourgeoisement and free-market stability in a crisis-ridden Ireland.

\section{Bibliography}

Amidon, Stephen (2004). 'An Evening of Long Goodbyes. This Man Is an Island', New York Times, 5 September. http://www.nytimes.com/2004/o9/o5/books/review/ an-evening-of-long-goodbyes-this-man-is-an-island.html [accessed 28.10.2017].

Battersby, Eileen (2015). 'The Mark and the Void, by Paul Murray. Review', Irish Times, 11 July. https://www.irishtimes.com/culture/books/the-mark-and-the-void-by-paulmurray-review-1.2277627 [accessed 28.10.2017].

Coffey, Edel (2015).“"There's a little banker in all of us”-Writer Paul Murray', Irish Independent, 22 July. https://www.independent.ie/entertainment/books/theres-a-littlebanker-in-all-of-us-writer-paul-murray-31390674.html [accessed 28.10.2017].

Cotterill, Joseph (2011). 'World's Best Bank (2006 Vintage)', Financial Times, 11 September. https://ftalphaville.ft.com/2011/02/11/485311/worlds-best-bank-20o6-vintage/ [accessed 28.10.2017].

Cullen, Loius M. (2012). 'Bankers, Bureaucrats, Booms and Bust', The Irish Review, 45 (Autumn), pp. 1-18.

Debord, Guy (1998). Comments on the Society of the Spectacle. (London, New York: Verso).

Dix, Hywel (2015). 'On Balkanism and Orientalism. Undifferentiated Patterns of Perception in Literary and Critical Representations of Eastern Europe', Textual Practice, 29.5, pp. 973-91.

Fennelly, Amanda (2003). 'An Evening of Long Goodbyes by Paul Murray', RTE.ie, 16 June. https://www.rte.ie/entertainment/book-reviews/2003/o616/445522-murrayp/ [accessed 27.10.2017].

Foster, Aisling (2010). 'Plot Lost in Flawed Fogey Farce', The Irish Times, 10 May. www.irishtimes.com/news/plot-lost-in-flawed-fogey-farce-1.358548 [accessed 27.10.2017].

Goldsworthy, Vesna (1998). Inventing Ruritania. The Imperialism of the Imagination (New Haven, London: Yale University Press).

54 Debord (1998), p. 6. 
Hardt, Michael, Antonio Negri (2012). Declaration. https://antonionegriinenglish. files.wordpress.com/2012/05/93152857-hardt-negri-declaration-2012.pdf [accessed 28.10.2017].

Harney, Mary (2000). Remarks by Tánaiste Mary Harney at a Meeting of the American Bar Association in the Law Society of Ireland, Blackhall Place, Dublin on Friday 21 July 2000. https://archive.fo/CRrS3 [accessed 01.11.2017].

Joyce, James (1986). Ulysses [The Corrected Text]. (London: Penguin Books).

Keyes, John (1995). 'Nothing Twice', Fortnight, March, p. 40.

Kohn, Hans (1945). The Idea of Nationalism. A Study of Its Origins and Background (New York: The Macmillan Company).

Krugman, Paul (2009). 'Erin Go Broke', The New York Times, 19 April. http://www.nytimes.com/2009/o4/20/opinion/2okrugman.html [accessed 01.11.2017].

Lenihan, Brian (2010).'We All Partied', Prime Time RTE Television, 24 October. https://youtu.be/YK7w6fXoYxo [accessed o1.11.2017].

Murray, Paul (2004). An Evening of Long Goodbyes (London: Penguin Books).

Murray, Paul (2010). Skippy Dies (London: Penguin Books).

Murray, Paul (2016). The Mark and the Void (London: Penguin Books).

Murray-Brown, John, Neil Dennis (2008). 'Ireland Guarantees Six Banks' Deposits', Financial Times, 30 September. https://www.ft.com/content/2124f8f4-8eb9-11dd946c-oooo779fd18c [accessed o1.11.2017].

O'Brien, George (2012). The Irish Novel, 1960-2010 (Cork: Cork University Press).

O’Malley, Aidan (2020). 'Irish Writers and Europe,' in Eve Patten (ed.), Irish Literature in Transition, 1940-1980 (Cambridge: Cambridge University Press), pp. 66-82.

O’Toole, Fintan (2010). Ship of Fools. How Stupidity and Corruption Sank the Celtic Tiger (London: Faber and Faber).

Reyn, Irina (2004). 'Living as an Art Form while Losing a Fortune', San Francisco Chronicle, 5 September. http://www.sfgate.com/books/article/Living-as-an-art-formwhile-losing-a-fortune-2695667.php [accessed 28.10.2017].

RTÉ (2007). 'Ahern Apologises for Suicide Remark', RTE.ie, 4 July. https://www.rte.ie/ news/2007/0704/90808-economy/ [accessed 28.10.2017].

Wallace, Aminta (2015). 'Paul Murray, "The banks were full of basket cases"', The Irish Times, 18 July. https://www.irishtimes.com/culture/books/paul-murray-the-bankswere-full-of-basket-cases-1.2287206 [accessed 28.10.2017].

Wardle, Irving (1995). 'Dandy, but not quite fine', Independent on Sunday, 26 February. 